AHMAR METAKARYA: JURNAL PENGABDIAN MASYARAKAT

Available online at: http://journal.ahmareduc.or.id/index.php/AMJPM

Vol.1, No.1, Agustus 2021, Halaman 51-55.

p-ISSN 2807-3797 e-ISSN 2807-3576

\title{
Penyuluhan Vaksinasi Covid-19 di Desa Malitu
}

\section{Priska Anakoda ${ }^{1}$, Dwi Firaningsih ${ }^{1}$, Deviana Laurenzy Tadale ${ }^{1}$, Eliska Abdul Salam ${ }^{1}$, Africe Naromba ${ }^{2}$, Christina Entoh ${ }^{1}$, Lisda Widianti Longgupa ${ }^{1}$, Nurfatimah ${ }^{1}$, Yafet Edimon Maradindo $^{2}$, Kadar Ramadhan ${ }^{1^{*}}$ \\ ${ }^{1}$ Program Studi Diploma III Kebidanan, Poltekkes kemenkes Palu, Palu, Sulawesi Tengah, Indonesia \\ ${ }^{2}$ Puskesmas Tangkura, Palu, Sulawesi Tengah, Indonesia \\ *Email koresponden: kadarlaure@gmail.com}

\begin{abstract}
The increasing number of Covid-19 cases requires the government to accelerate the distribution of vaccines so that vaccination coverage increases. Vaccination aims to provide specific immunity against a certain disease so that if one day contracted the disease, it will not get sick or only experience mild illness. The purpose of this activity is to provide education about the Covid-19 vaccination. This activity was carried out in Hamlet 1 RT 1 Malitu Village on March 25, 2021. The target of this activity is 10 people in Hamlet 1 RT 1 Malitu Village. The method of this activity is to distribute leaflets to participants and then conduct counseling. Evaluation of this activity is by giving a pre-posttest. The results of the activity showed that there was an increase in public knowledge after counseling. We advise the public to always apply health protocols, maintain health, and body immunity through the food they eat to avoid Covid-19.
\end{abstract}

Keywords: Knowledge, Covid -19 Vaccine, Counseling.

\begin{abstract}
Abstrak
Kasus Covid-19 yang terus meningkat mengharuskan pemerintah mepercepat distribusi vaksin agar cakupan vaksinasi meningkat. Vaksinasi bertujuan untuk memberikan kekebalan spesifik terhadap suatu penyakit tertentu sehingga bila suatu saat terjangkit penyakit tersebut maka tidak akan sakit atau hanya mengalami sakit ringan. Tujuan kegiatan ini adalah untuk memberikan penyuluhan tentang vaksinasi Covid19. Kegiatan ini dilaksanakan di Dusun 1 RT 1 Desa Malitu pada tanggal 25 Maret 2021. Sasaran kegiatan ini adalah 10 orang masyarakat yang ada di Dusun 1 RT 1 Desa Malitu. Metode kegiatan ini adalah membagikan leaflet kepada peserta kemudian melakukan penyuluhan. Evaluasi kegiatan ini adalah dengan pemberian pre-posttest. Hasil kegitan diperoleh ada peningkatan pengetahuan masyarakat setelah dilakukan penyuluhan. Kami menyarankan masyarkat untuk selalu menerapkan protokol kesehatan, menjaga kesehatan, dan imunitas tubuh lewat makan yang dikonsumsinya untuk terhindar dari Covid- 19 .
\end{abstract}

Kata Kunci: Pengetahuan, Vaksin Covid -19, Penyuluhan. 


\section{A. PENDAHULUAN}

Jumlah kasus Covid-19 makin meningkat. Per tanggal 25 Maret 2021 terdapat penambahan kasus harian sebesar 6.107 kasus, menjadikan total kasus di Indonesia menjadi 1.482 .559 kasus dengan 125.279 kasus aktif dan jumlah kematian menembus 40 ribu (Adyatama \& Budiman, 2021; Guritno \& Krisiandi, 2021; Tim Detikcom, 2021). Untuk propinsi Sulawesi Tengah, total kasus sebanyak 11.045 dengan jumlah kematian 292 kasus (Case Fatality Rate [CFR] 2,64\%), sedangkan untuk Kabupaten Poso jumlah kasus 1613 dengan jumlah kematian 44 kasus (CFR $2,73 \%$ ). Dengan jumlah kasus yang tinggi ini, kabupaten Poso berstatus zona merah atau risiko tinggi (Alifah \& Prasetya, 2021; Tanggap Covid-19 Sulawesi Tengah, 2021).

Untuk mencegah meningkatnya kasus Covid-19 lebih tinggi lagi, proses pemberian vaksinasi harus segera dilakukan. Sejak November 2020, beberapa varian baru telah diidentifikasi, meningkatkan kekhawatiran tentang penularan yang lebih tinggi dan potensi pengurangan efektivitas vaksin yang saat ini tersedia. Produsen dan regulator sedang menyelidiki solusi potensial, termasuk pengembangan vaksin baru yang diperbarui, baik untuk vaksinasi primer atau untuk digunakan sebagai booster bagi mereka yang sudah divaksinasi. Bukti efektivitas vaksin terhadap penularan SARS-CoV-2 saat ini terbatas, namun sinyal positif diamati dari uji coba vaksin dan studi berbasis populasi (Baden et al., 2021; Dagan et al., 2021; Shah et al., 2021; Voysey et al., 2021). Distribusi vaksin yang cepat terhadap COVID-19 dapat memungkinkan intervensi nonfarmasi berkurang dalam beberapa bulan mendatang. Strategi vaksinasi yang efisien dan efektif harus diarahkan oleh tujuan yang jelas. Oleh karena itu, penetapan dan prioritas tujuan yang jelas dan terukur untuk strategi vaksinasi COVID-19 menjadi sangat penting (European Centre for Disease Prevention and Control, 2021).

Salah satu masalah dalam pemberian vaksinasi adalah adanya penolakan dari beberapa kalangan masyarakat. Survei Indikator Politik awal tahun 2021 menunjukan 41\% masyarakat menolak untuk divaksinasi (Bona, 2021), survei Lembaga Survei Indonesia (LSI) 6 bulan kemudian menunjukan 36,4\% masyarakat tidak bersedia menerima vaksinasi (CNN Indonesia, 2021). Penelitian yang dilakukan di Sulawesi Tengah menunjukan $64,7 \%$ responden belum bersedia divaksinasi (Ichsan et al., 2021). Hal ini terjadi akibat persepsi yang salah terkait vaksinasi karena masih kurangnya komunikasi yang baik dari tenaga kesehatan untuk meyakinkan masyarakat tentang keefektifan vaksin Covid-19 (Astuti et al., 2021). Walaupun mengalami penurunan, angka ini masih dapat menyebabkan terciptanya kekebalan komunitas tidak terjadi. Menjadi tugas yang berat yang harus dilakukan oleh pemerintah jika ingin cakupan vaksinasi Covid-19 ini dapat meningkat.

Lokasi Desa Malitu yang cukup terpencil dan letaknya yang terpusat pada satu tempat cukup menghawatirkan jika kasus Covid-19 menjangkit masuk ke desa. Dengan posisi seperti itu pula sangat baik untuk melakukan pencegahan karena pintu masuk hanya 1 tempat. Penjagaan di pintu masuk harus ketat. Sampai saat ini, kasus Covid-19 hanya 1 orang dan berhasil sembuh. Dengan adanya program vaksinasi Covid-19 ini, diharapkan warga mau divaksinasi sehingga kejadian gejala sedang atau berat jika nantinya tertular Covid-19 bisa disembuhkan. Manfaat vaksin jauh lebih besar dibandingkan risiko sakit karena terinfeksi bila tidak divaksin (Kementerian Kesehatan Republik Indonesia, 2021). Tujuan dari kegiatan ini adalah untuk memberika penyuluhan kepada warga tentang pentingnya vaksinasi Covid-19 di desa Malitu.

\section{B. METODE DAN PELAKSANAAN}

Kegiatan ini merupakan salah satu intervensi kegiatan Praktik Daerah Terpencil, Pedalaman, dan Kepulauan (DTPK) Prodi D-III Kebidanan Poso, Poltekkes Kemenkes Palu.Kegiatan penyuluhan ini dilakukan di Dusun 1 RT 1 Desa Malitu pada hari Kamis, 25 Maret 2021. Desa Malitu merapakan salah satu desa di kecamatan Poso Pesisir Selatan, Kabupaten Poso. Sasaran kegiatan adalah Masyarakat yang ada di Dusun 1 RT 1 Desa Malitu. Kami membatasi jumlah peserta hanya 10 orang karena adanya pandemik Covid-19 ini, sehingga peserta bisa menjaga jarak satu sama lain. Prosedur kegiatan yang pertama kami lakukan membagikan kuesioner pretest. Setelah peserta selesai mengisi pretest maka kami membagikan leaflet, lalu dilanjutkan denganpenyuluhan tentang Vaksin Covid-19. Setelah melakukan penyuluhan kami lanjutkan 
Anakoda, P., Firaningsih, D., Tadale, D. L., Salam, E. A., Naromba, A., Entoh, C., Longgupa, L. W., Nurfatimah ${ }^{1}$, Maradindo, Y. E., Ramadhan, K., (2021). Penyuluhan Vaksinasi Covid 19 di Desa Malitu. Ahmar Metakarya: Jurnal Pengabdian Masyarakat, 1 (1), 5155.

dengan kegiatan Tanya jawab tentang vaksin covid-19. Mengakhiri kegiatan kami membagikan kuesioner posttest untuk mengevaluasi pengetahuan masyarakat. Kuesioner pre-posttest berisi 10 pertanyaan dengan pilihan jawaban benar-salah.

\section{HASIL DAN PEMBAHASAN}

Kegiatan penyuluhan tentang vaksin Covid-19 ini dilakukan pada masyarakat yang ada di Dusun 1 RT 1 Desa Malitu. Kegiatan ini bekerjasama dengan bidan desa dan puskesmas Tangkura. Kegiatan dilakukan di rumah salah satu warga. Dalam pelaksanaan kegiatan, kami melaksanakan protokol kesehatan dengan menggunakan masker dan menjaga jarak. Dokumentasi kegiatan seperti terlihatan pada gambar 1 dan 2.
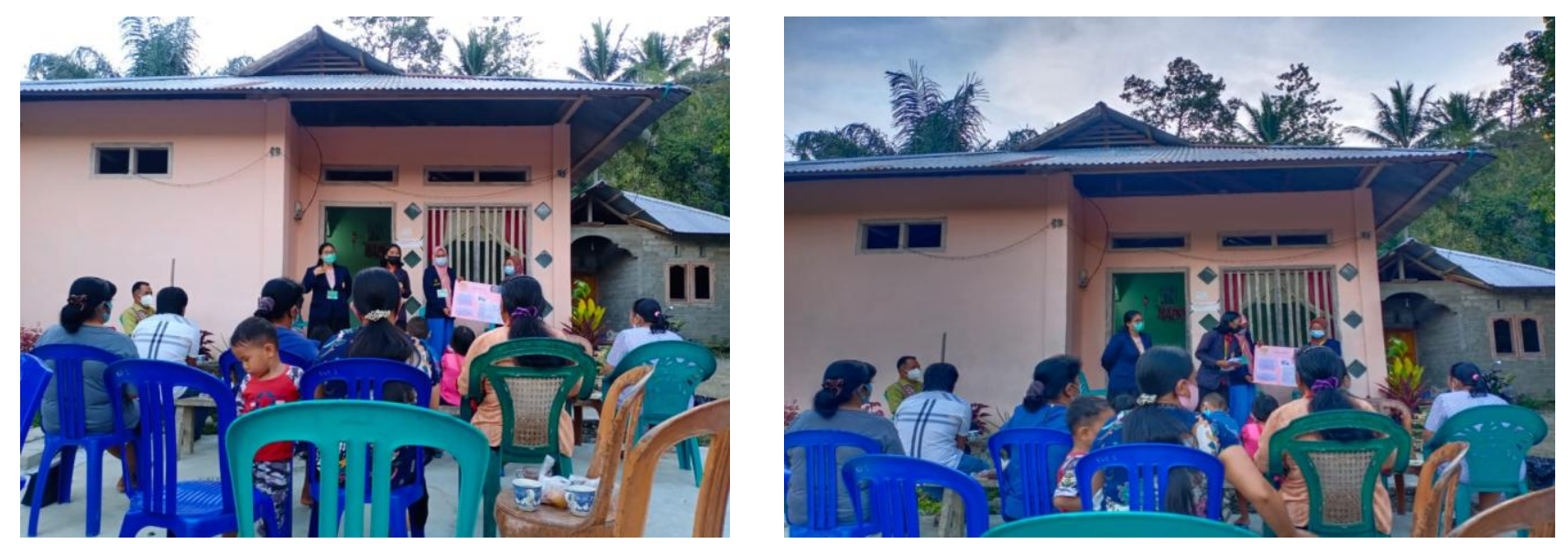

Gambar 1 dan 2 . Pelaksanaan Penyuluhan

Berdasarkan evalusi yang kami lakukan, terjadi peningkatan pengetahuan peserta tentang vaksinasi Covid-19, dimana rata-rata sebelum adalah 38 meningkat menjadi 67 setelah penyuluhan. Evaluasi kegiatan seperti terlihat pada gambar 3. Setelah dilakukannya penyuluhan dapat dilihat tingkat pengetahuan masyarakat yang bertambah dengan adanya penyuluhan ini. Hal tersebut dilihat dari keantusiasan masyarakat saat mengikuti penyuluhan lewat respon masyarakat dalam memberi dan menjawab pertanyaan.

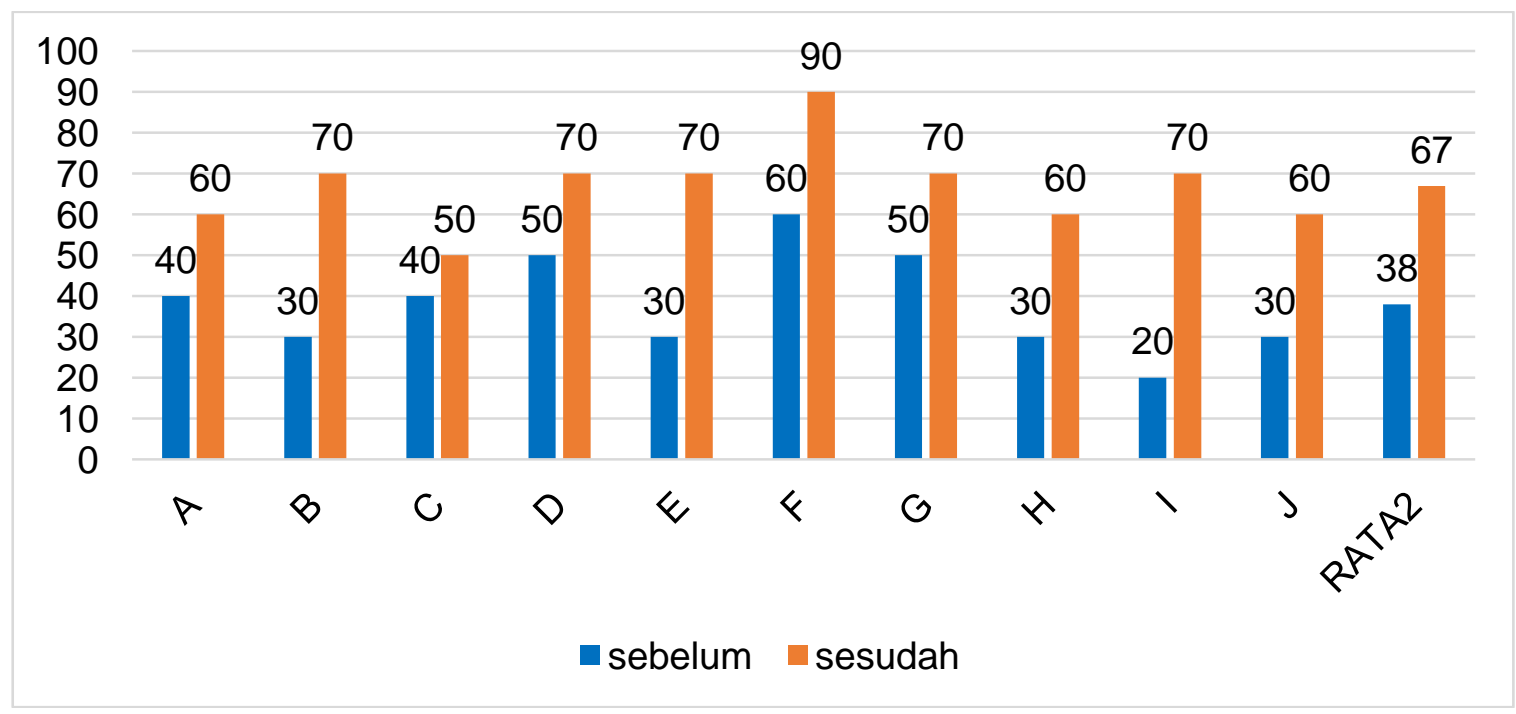


Gambar 3. Grafik peningkatan pengetahuan warga tentang vaksinasi

Kami sangat berharap agar cakupan vaksinasi tinggi sehingga dapat membentuk kekebalan kelompok. Vaksin melatih sistem imun kita untuk menciptakan protein yang dapat melawan penyakit, yang disebut 'antibodi', seperti jika kita terpapar pada suatu penyakit, tetapi perbedaan pentingnya adalah bahwa vaksin bekerja tanpa membuat kita sakit. Orang yang telah diimunisasi terlindung dari penyakit yang bersangkutan dan tidak dapat menyebarkannya, sehingga memutus rantai penularan (WHO Indonesia, 2021).

Proses pemberian edukasi berkelanjutan melalui penyuluhan kesehatan harus terus dilakukan, penerapan protokol kesehatan harus benar-benar dilaksanakan, terutama pada kelompok berisiko seperti lanjut usia (Fredy Akbar K et al., 2021), selain itu edukasi ini penting untuk menghalau berita-berita yang tidak benar (hoax)terkait dengan vaksin Covid-19 (Hoax Buster, 2021; Kementerian Kesehatan R.I., 2021) Memakai masker, menjaga jarak, mencuci tangan saat ada kegiatan maupun saat ibadah harus dilakukan dilakukan untuk mengurangi risiko tertular Covid-19 (Simbolon et al., 2021).

\section{KESIMPULAN}

Dari hasil pelaksanaan kegiatan ini dapat disimpulkan bahwa terdapat penambahan pengetahuan warga tentang vaksinasi Covid-19 di RT 1 desa Malitu. Diharapkan pemberian edukasi seperti ini harus terus dilakukan oleh puskesmas Tangkura, bekerjasama dengan Pemerintah Desa Malitu sehingga seluruh warga nantinya bersedia untuk divaksinasi.

\section{UCAPAN TERIMA KASIH}

Terimakasih kepada Kepala Desa Malitu yang turut membantu dalam terlaksananya kegiatan ini.

\section{DAFTAR PUSTAKA}

Adyatama, E., \& Budiman, A. (2021). Update Covid-19 per 25 Maret 2021, Jumlah Kasus Kematian Tembus 40 Ribu. Tempo.Co. https://nasional.tempo.co/read/1445944/update-covid19-per-25-maret-2021-jumlah-kasus-kematian-tembus-40-ribu

Alifah, D. N., \& Prasetya, I. (2021). Update Kasus Covid-19 di Sulawesi Tengah Kamis 25 Maret 2021, 1 Orang Meninggal dan 24 Kasus Positif. Tribunpalu.Com. https://palu.tribunnews.com/2021/03/25/update-kasus-covid-19-di-sulawesi-tengah-kamis-25maret-2021-1-orang-meninggal-dan-24-kasus-positif

Astuti, N. P., Nugroho, E. G. Z., Lattu, J. C., Potempu, I. R., \& Swandana, D. A. (2021). Persepsi Masyarakat terhadap Penerimaan Vaksinasi Covid-19: Literature Review. Jurnal Keperawatan, 13(3), 569-580. https://doi.org/10.32583/keperawatan.v13i3.1363

Baden, L. R., El Sahly, H. M., Essink, B., Kotloff, K., Frey, S., Novak, R., Diemert, D., Spector, S. A., Rouphael, N., Creech, C. B., McGettigan, J., Khetan, S., Segall, N., Solis, J., Brosz, A., Fierro, C., Schwartz, H., Neuzil, K., Corey, L., ... Zaks, T. (2021). Efficacy and Safety of the mRNA-1273 SARS-CoV-2 Vaccine. New England Journal of Medicine, 384(5), 403-416. https://doi.org/10.1056/NEJMoa2035389

Bona, M. F. (2021). Komisi IX: Jangan Anggap Remeh Hasil Survei 41\% Masyarakat Tolak Divaksin. Beritasatu.Com. https://www.beritasatu.com/kesehatan/736631/komisi-ix-jangananggap-remeh-hasil-survei-41-masyarakat-tolak-divaksin

CNN Indonesia. (2021). Survei LSI: 36,4 Persen Masyarakat Tak Mau Divaksin Covid-19. Cnnindonesia.Com. https://www.cnnindonesia.com/nasional/20210718163102-20669198/survei-Isi-364-persen-masyarakat-tak-mau-divaksin-covid-19

Dagan, N., Barda, N., Kepten, E., Miron, O., Perchik, S., Katz, M. A., Hernán, M. A., Lipsitch, M., Reis, B., \& Balicer, R. D. (2021). BNT162b2 mRNA Covid-19 Vaccine in a Nationwide Mass Vaccination Setting. New England Journal of Medicine, 384(15), 1412-1423. https://doi.org/10.1056/NEJMoa2101765

European Centre for Disease Prevention and Control. (2021). Objectives of vaccination strategies against (Issue Apriil). https://www.ecdc.europa.eu/sites/default/files/documents/Objectives-of- 
Anakoda, P., Firaningsih, D., Tadale, D. L., Salam, E. A., Naromba, A., Entoh, C., Longgupa, L. W., Nurfatimah ${ }^{1}$, Maradindo, Y. E., Ramadhan, K., (2021). Penyuluhan Vaksinasi Covid 19 di Desa Malitu. Ahmar Metakarya: Jurnal Pengabdian Masyarakat, 1 (1), 5155.

vaccination-strategies-against-COVID-19.pdf

Fredy Akbar K, Hamdan Nur, Agustan, I., \& Dinda Cendana Wangi. (2021). Peningkatan Pengetahuan Lansia Tentang Kesiapsiagaan Bencana Nasional Covid-19 di Desa Rumpa Kecamatan Mapili Kabupaten Polman. Poltekita: Jurnal Pengabdian Masyarakat, 2(1), 1-7. https://doi.org/10.33860/pjpm.v2i1.247

Guritno, T., \& Krisiandi. (2021). UPDATE 25 Maret: Ada 125.279 Kasus Aktif Covid-19 di Indonesia. Kompas.Com. https://nasional.kompas.com/read/2021/03/25/18335211/update-25maret-ada-125279-kasus-aktif-covid-19-di-indonesia

Hoax Buster. (2021). [SALAH] Video "Potensi Bahaya Vaksin COVID-19." Covid19.Go.Id. https://covid19.go.id/p/hoax-buster/salah-video-potensi-bahaya-vaksin-covid-19

Ichsan, D. S., Hafid, F., Ramadhan, K., \& Taqwin, T. (2021). Determinan Kesediaan Masyarakat menerima Vaksinasi Covid-19 di Sulawesi Tengah. Poltekita: Jurnal Ilmu Kesehatan, 15(1), 1-11. https://doi.org/10.33860/jik.v15i1.430

Kementerian Kesehatan R.I. (2021). HOAX: Vaksin COVID-19 Mengandung Mikrocip Magnetis. Kemkes.Go.Id.

https://sehatnegeriku.kemkes.go.id/baca/beritautama/20210528/1137831/hoax-vaksin-covid-19-mengandung-mikrocip-magnetis/

Kementerian Kesehatan Republik Indonesia. (2021). Frequently Asked Questions (FAQ) Pelaksanaan Vaksinasi Covid-19. Kementerian Kesehatan R.I.

Shah, A. S. V, Gribben, C., Bishop, J., Hanlon, P., Caldwell, D., Wood, R., Reid, M., Mcmenamin, J., Goldberg, D., Stockton, D., Hutchinson, S., Robertson, C., Mckeigue, P. M., Colhoun, H. M., \& Mcallister, D. A. (2021). Effect of vaccination on transmission of COVID-19: an observational study in healthcare workers and their households. MedRxiv, 2021.03.11.21253275. https://doi.org/10.1101/2021.03.11.21253275

Simbolon, V. A., Manullang, P. O., \& Sitanggang, Y. E. (2021). Memutus Mata Rantai Penularan Virus Covid-19 melalui Penggunaan Masker dan Penggunaan Alat Dispenser Hand Sanitizer di Tempat Ibadah. Poltekita: Jurnal Pengabdian Masyarakat, 2(1), 14-20. https://doi.org/10.33860/pjpm.v2i1.290

Tanggap Covid-19 Sulawesi Tengah. (2021). Sebaran Kasus Covid-19 Sulawesi Tengah. Corona.Sultengprov.Go.Id. http://corona.sultengprov.go.id/

Tim Detikcom. (2021). Ini Sebaran 6107 Kasus Baru Corona 25 Maret 2021. Detik.Com. https://news.detik.com/berita/d-5507885/ini-sebaran-6107-kasus-baru-corona-25-maret-2021

Voysey, M., Costa Clemens, S. A., Madhi, S. A., Weckx, L. Y., Folegatti, P. M., Aley, P. K., Angus, B., Baillie, V. L., Barnabas, S. L., Bhorat, Q. E., Bibi, S., Briner, C., Cicconi, P., Clutterbuck, E. A., Collins, A. M., Cutland, C. L., Darton, T. C., Dheda, K., Dold, C., ... Zuidewind, P. (2021). Single-dose administration and the influence of the timing of the booster dose on immunogenicity and efficacy of ChAdOx1 nCoV-19 (AZD1222) vaccine: a pooled analysis of four randomised trials. The Lancet, 397(10277), 881-891. https://doi.org/10.1016/S01406736(21)00432-3

WHO Indonesia. (2021). Tanya Jawab: Lockdown dan herd immunity. Who.Int. https://www.who.int/indonesia/news/novel-coronavirus/qa/qa-lockdown-and-herd-immunity 